\title{
MACROBENTHIC INVERTEbRATES IN RELATION TO SEDIMENT PROPERTIES IN SOME FISH FARMS.
}

\section{Mohamed R. A. Fishar and Ragab M. Abdel-Regal}

National institute of Oceanography and fisheries

Al-Kanater Al-Khayria, Egypt.

Key words : Macrobenthos, Fish ponds, Sediments.

(Received Mar.10, 1998)

\section{ABSTRACT}

Techanical analysis, some chemical properties of sediment, composition and distribution of macrobenthic invertebrates were studied in ten fish ponds at El-Fayoum Governorate (Egypt). The study showed that the nature of sediment ranged between sandy loam and clayey soils, while the sediment $\mathrm{pH}$ lied in the alkaline side. The community of benthos was represented by four groups (Annelida, Crustacea, Insecta and Mollusca).

The most important factors affecting the composition and distribution of benthic community include nature of the bottom sediment, soil salinity, and its organic matter content, besides the number of rearing stocked fishes.

\section{INTRODUCTION}

The fish production in Egypt depends largely on the inland water bodies of the country. Recently, attention has been turned towards fish farming for increasing fish production.

The culture of various fish species is established in different regions of Egypt. In Fayoum Governorate, many fish farms were distributed around Lake Qarun. These farms are depending on the agricultural drainage water. Most of these farms are simple and primitive with wide variations in levels of managment. Some of these fish ponds were used for rearing tilapias, while the others were used to produce mullets. They are fertilized with inorganic fertilizers ( $1 / 2 \mathrm{~kg}$ urea and $750 \mathrm{gm}$ superphosphate per feddan, Mageed, 1996). 
The environmental conditions in the fish farms are very important for fish production. Bottom sediments of fish ponds are considered as the main source of nutrients which directly or indirectly nourishes the fishs. Hepher and Pruginin (1981) mentioned that the most suitable soil for fish farming is the heavy texture soil where seepage is very low. Abdel Regal et al. (1996) found that a soil which contains high percent of clay particles increased the fish production compared with that of low percent of fine particles. El-Sarraf (1994) mentioned that when aquatic organisms and organic detritus reaching the sediment of lakes or pond's bottom, they are easily degarded to carbohydrates and amino-acids. This leads to increasing of eutrophication in the fish ponds.

Zooplankton assemblage and their role as natural food for the cultivated fishes in El-Fayoum fish farms were studied by Mageed (1996) who showed that rotifers and juvenile stages of Copepoda are predominant organisms in the fish ponds.

Bottom fauna plays an important role as natural diet for many fishes. Al-Kholy and Abdel-Malek (1972) recorded many benthic forms (polychaetes, ostracods, amphipods and molluscs) in the alimentary canal of Tilopia zillii in Lake Qarun. The analysis of gut contents of Cyprinus carpio at El-Serow fish farm showed that these fishes feed mainly on bottom fauna (Bishai et al., 1973).

The benthic community in the ponds are subjected to wide variations in the environmental conditions, mechanical and chemical composition of bottom sediment, number and species of stocking fishes.

The aim of this investigation is to give a clear picture of benthic community and their distribution in fish farms and drawing a relationship between properties of pond sediments and abundance of certain benthic species.

\section{A- Sediment :}

\section{MATERIAL AND METHODS}

Sampling of bottom sediments and bottom fauna were carried out from ten fish ponds during 1996 by using Ekman grab (with opening area of 
$\left.250 \mathrm{~cm}^{2}\right)$. All these ponds were stocked with Tilapia sp. and Mugil sp.. The characteristics of fish pond's water and their number of stocked fishes were determined by team work of the Inland Water and Aquaculture Branch, National Institute of Oceanography and Fisheries (Table, 1).

\section{1- Mechanical analysis:}

Particle size distribution of bottom sediment was carried out by the international pipette method using sodium hexametaphosphate as dispersing reagent according to Kilmer and Alexander (1949).

\section{2- Chemical analysis:}

Organic matter percent was determined according to Walkely and Black method outlined in Jackson (1967). Soil pH was measured in $1: 2.5$ soil : water suspension using a Beckman $\mathrm{pH}$ meter. Electrical conductivity (EC) was determined in soil water extract using a conductivity meter. Soluble ions in the soil extract were determined according to Jackson (1967), as follows :

Calcium and magnesium were determined by titration against sodium EDTA solution. Sodium and potassium were measured by flame photometer. Chlorides were determined by titration against $\mathrm{AgNO}_{3}$ solution, while carbonates and bicarbonates were determined by titration against diluted $\mathrm{H}_{2} \mathrm{SO}_{4}(0.02 \mathrm{~N})$. Sulphate salts were determined by precipitation as barium sulphate.

\section{B-Bottom fauna:}

Quantitative sampling of bottom fauna was performed monthly, five times during 1996. More than one grab from each pond were hauled. The collected samples were washed in the field through a small hand net of 500 $\mu \mathrm{m}$ mesh diameter. The samples were stored in plastic jars after adding $7 \%$ formalin solution. Sorting and identification of the different species were carried out in the laboratory. The different groups were counted and weighed after drying on filter papers for five minutes to remove excessive water. Results were given as total numbers of bottom fauna per square meter as well as their biomass in gm fresh weight per square meter (G.F.W. $/ \mathrm{m}^{2}$ ). 


\section{RESULTS}

\section{A- Sediment:}

1- Mechanical analysis:

Particle size distribution of the investigated fish ponds sediment showed that, the nature of the bottom sediment varied from sandy loam to clayey soil.

Table (2) shows also that sediment of both pond 2 and 5 was sandy loam, pond 9 sediment was sandy clay loam. The texture of sediment of ponds 1,7 and 8 was clay loam soil while the sediment of ponds $3,4,6$ and 10 was clay soil. Clay percent of these ponds varied from $11.87 \%$ (in pond 5) to $64.59 \%$ (in pond 4) while sand percent ranged between $10.57 \%$ (in pond 4) to $71.51 \%$ (in pond 5).

\section{2- Chemical properties:}

Organic matter percent of the investigated soil samples was relatively low. The lower values of organic matter were recorded in the sand loam soils, while the highest value (1.69\%) was at pond 9 which was characterized by sandy clay loam bottom.

Sediment $\mathrm{pH}$ follows the opposite trend of that in organic matter, where their values were high in ponds 2 and 5 but the lowest value (8.00) was recorded in pond 9 . It can be seen that $\mathrm{pH}$ of the sediment lied in the alkaline side.

Soil salinity of the investigated fish ponds was estimated from our measurment of the electrical conductivity (EC) in the soil extracts. $E C$ values ranged from $1.7 \mathrm{mmhos} / \mathrm{cm}$ (in ponds 2 and 5) to reach $3.9 \mathrm{mmhos} / \mathrm{cm}$ in two ponds (7 and 10). In other words soil salinity of the fish ponds bottom ranged between $0.11 \%$ to $0.25 \%$.

Table (3) shows the results of soluble ions. Sodium concentration in the studied fish ponds was relatively high if compared with the other cations followed by magnesium, calcium and potassium. 
Values of soluble sodium ranged from 15 to $23.9 \mathrm{ml} / 100 \mathrm{~g}$ soil, the lowest and the highest values were recorded in ponds 2 and 7, respectively. Magnesium values varied between 0.6 (in pond no. 4) to $3.0 \mathrm{ml} . / 100 \mathrm{~g}$ (in pond no. 1). Calcium values ranged from 0.3 to $0.8 \mathrm{ml} / 100 \mathrm{~g}$, while potassium ranged from 0.46 (in pond 5) to $1.17 \mathrm{ml} / 100 \mathrm{~g}$ (in pond no. 3 ).

Chloride ion followed the same trend of both salinity and soluble sodium. At the same time, sulphate followed the same trend of both calcium and magnesium ions.

\section{B- Bottom fauna :}

The benthic community in the studied fish ponds was represented by four groups, Annelida, Crustacea, Insecta and Mollusca.

Annelida was represented by two species, an oligochaete belonging to family Tubificidae, and the polychaete Neries diversicolor. Crustacea were represented by three species, the amphipod, Corophium oriantalis, the decapod, Palaemon sp. and the ostracod, Cypridies torosa. Insecta represented by larvae and pupae of family Chironomidae, while Mollusca were represented by Melanoides tuberculata.

\section{Composition of benthos:}

The composition indicated by number and biomass of macrobenthic invertebrates in the different fish ponds during the study period varied from a pond to another (Table, 4$)$. The highest population density was recorded in pond 4 where 900 organisms $/ \mathrm{m}^{2}$ were observed. This was due to intensive abundance of the amphipod Corophium oriantalis. On the other hand, the lowest number of benthos was observed in pond 7 which can be attributed to the decline of major benthic forms than other ponds.

Concerning biomass, the highest weight was recorded in pond 5 which was mainly due to occurrence of the heavy crustacean Palaemon sp. This species form $97.71 \%$ of the total biomass of benthos. Pond number 4 showed the lowest biomass value $\left(0.56 \mathrm{G} . \mathrm{F} . \mathrm{W} . / \mathrm{m}^{2}\right)$ than that recorded in the other ponds. 


\section{$\cdot$ Discussion}

The community of benthic invertebrates in fish ponds is subjected to wide variations with of environmental conditions such as water quality, chemical properties of bottom sediment and the biological conditions prevailing in the different localities.

Welch (1952), mentioned that nature of bottom sediment has a selective effect on the abundance of benthos. Each type of sediment is associated with specific faunal composition. Many authers (Stephenson and Williams, 1971 and Pearson and Stanley, 1976) suggested the importance of bottom deposits as a determinal effect on the distribution of bottom fauna. Ponds number 7, $8 \& 9$ which have a medium and fine soils (sandy clay loam or clay loam soils) were charecterized by the presence of Crustacea and Insecta. This result agrees with the result of Coleman et al (1978) who found that the bottom fauna of medium and fine sand and mud of the shallow water in port Victoria was dominated by polychaetes, crustaceans and molluscs. The polychaete Nereis diversicolor showed their highest counts in ponds number $3,6 \& 10$ where their bottom sediment consists mainly of mud (silt and clay). The amphipod Corophium oriantalis was found in all investigated fish ponds except in pond 5 (Sandy loam sediment bottom). This indicates that the above two species can live in all sediment types but prefer the clayey soil. The feeding habits of these species (mud feeders) may explain their abundance in this pond. This agrees with the observations of Fishar (1993) in Lake Qarun. The mullusc Melanoides tuberculata was recorded only in pond 2 which has sandy loam sediment and contains the lowest percent of clay particles. This may be due to its sandy bottom nature (El-Shebrawy ,1993).

The $\mathrm{pH}$ of sediment of the fish ponds is considered one of the most important factors affecting their productivity. In the studied fish farms, the $\mathrm{pH}$ lies at the alkaline side and its values ranged between 8.0 and 8.4. The $\mathrm{pH}$ values in the studied farms showed a negative correlation with percent of organic matter. The simple regression was : $\mathrm{pH}=8.38-0.25 \mathrm{OM} \%(\mathrm{r}=-$ 0.78). The effect of $\mathrm{pH}$ on the distribution and composition of benthic organisms was demonstrated by many works (Pennak, 1953; Friday, 1987 \& Smith $e t a l, 1990)$. In the present study, it is noticeable that the fish ponds with higher $\mathrm{pH}$ values are rich with Crustacea and Insecta. 
The electrical conductivity (EC) of soil extracts of the investigated fish ponds ranged between 1.7 and $3.9 \mathrm{mmhos} / \mathrm{cm}$. The sandy loam soils had the lowest EC value while the clay loam soils had the highest value (3.9 $\mathrm{mmhos} / \mathrm{cm}$ ). The increase in soil salinity in the two fish ponds with clay loam texture may be correlated with the increase in sodium salts and perhaps the increase in water salinity of these ponds. Statistical analysis showed that there was a positive correlation between soil salinity and total soluble salts ( $\mathbf{r}$ $=0.98$ ). The same trend was observed between the electrical conductivity and soluble chlorides $(r=0.94)$. Regarding the effect of soil salinity on distribution of botton fauna in the fish ponds, it was found that, the polychaete Neries diversicolor which appeared in ponds $2,6,9 \& 10$ where the salinity ranged between 1.7 and $3.9 \mathrm{mmhos} / \mathrm{cm}$. This agrees with Smith (1955 \& 1956) who reported that $N$. divesicolor tolerates essentially fresh water and variable salinities from estuarine habitats to hypersaline conditions. On the other hand, the ponds which had the lowest salinity were characterized by dominance of larvae and pupae of Chironomidae.

Soluble sodium salts were the most dominant cations in the studied fish pond' soils. Statistical analysis showed a high correlation between $\mathrm{Na}^{+}$ and $\mathrm{Cl}^{-}$concentration $(\mathrm{r}=0.98)$. The simple regressions were $\mathrm{Na}^{+}=11.28+0.95 \mathrm{Cl}^{-} \& \mathrm{Cl}^{-}=-11.02+1.01 \mathrm{Na}^{+}$

Meanrhile, there was a positive correlation between sulphate salts and both calcium and magnesium cations in the sediment extracts. The simple regression equations were :

$\mathrm{Mg}^{++}=-5.35+0.54 \mathrm{SO}_{4}^{--} \& \mathrm{SO}_{4}{ }^{--}=10.55+1.44 \mathrm{Mg}^{++}$

On the other hand no clear relation between the soluble ions and distribution of bottom fauna could be drawn from the studied fish ponds.

Organic matter percentage (OM\%) of the most investigated fish ponds was relatively low. It was less than $0.5 \%$ in ponds $2 \& 5$ where their bottom mainly consists of sand. At the same time, the highest value of organic matter (1.69\%) was recorded in pond 9, where the $\mathrm{pH}$ was the lowest. The simple regression equation was :

O.M\% $=20.93-2.46 \mathrm{pH} \quad(\mathrm{r}=-0.78)$.

The same trend was reported by Abdel-Regal (1986 \& 1991) in the sediment of El-Serow fish farm and El-Raswa fish farm located in Dakahlia and Port Saied Governorates, respectively. Fish ponds poor in their organic matter 
content were poor in bottom fauna. This result agrees with Row et al (1975) \& Pearson and Stanley (1976).

The absence of live molluscs from the benthic community (except Melanoides tuberculata in pond 2) indicates the unsuitability of farm's environment for molluscan life. This observation was also recorded in ElSerw fish farm (Abdel-Gawad, 1993).

The highest population density of bottom fauna was recorded in pond 4 which contains the lowest number of reared fish. This phenomenon was reversed in pond $7 \& 8$, which contained the lowest counts of benthos and the highest number of stocked fish. This may indicate that benthic organisms represent a part of the main food items in the fish ponds.

From the present study, it can be concluded that the composition and distribution of benthic community in the different fish ponds are affected by the nature and properties of pond's sediment beside the stocked fish.

\section{REFERENCES}

Abdel-Gawad, S. S. E. (1993). Studies on macrobenthic invertebrates in ElSerw fish farm region. M. Sc. Thesis, Fac. Sci., Mansoura Univ., $203 \mathrm{pp}$.

Abdel-Regal, R M. (1986). Some chemical and physical variations in soil properties under conditions of fish farming. M. Sc. thesis, Fac. Agric. Moshtohor, Zagazig Univ., Benha Branch, Egypt.

Abdel-Regal, R M. (1991). Effect of some treatments used in fish farming on soil properties and fish production. Ph. D. thesis, Fac. Agric.

Moshtohor, Zagazig Univ., Benha Branch, Egypt.

Abdel-Regal, R. M.; El. A., El-Shanawani and H. M., El-Kholi (1996). Effect of different diets on fish production and soil properties of fish farms. Menofiya J. Agric. Res., 21 (1). 201 - 212.

Al-Kholy, A. A. and S. A., Abdel-Malek (1971). Food and feeding habits of some Egyptian fishes in Lake Qanun. part I. Tilapia zillii A. according to different localities. Bull. Inst. Oceanogr. \& Fish., 2. 187 - 201. 
Macrobnthic invertebrates in relation to sediment properties

Coleman, N; W., Cuff; M., Drummond and J. D., Kudenavov (1978). A quantitative survey of macrobenthos of Western paort, Victoria, Aust. J. Mar. Freshwater Res., 29 (4). 445 - 466.

Bishai, H. M.; S. A., Abdel-Malek and W., Labib (1973). Food and feeding habits of Cyprinus carpio L. at Serw fish farm, Egypt. Bull. Inst. Oceanogr. \& Fish., 3. $203-216$.

El-Saraf, W. M. (1994). Carbohydrate content of sediments in some Aquatic habitats (Egypt). Bull. Nat. Inst. Oceanogr. \& Fish., A.R.E., 20 (1). $43-58$.

El-Shebrawey, G. M. (1993). Studies on the invertebrates in Wadi El-Rayan depression, M. Sc. Thesis, Fac. Sci., Zagazig Univ., 183 pp.

Fishar, M. R. A. (1993). Studies on bottom invertebrates in Lake Qarun, Egypt. M. Sc. Thesis, Fac. Seience, Benha, Zagazig University, 177 p.

Friday, L. E. (1987). The diversity of macroinvertebrates and macrophyte communities in ponds. Freshwater Biol., 18.87 - 104.

Hepher, B. and Pruginin, Y. (1981). Commercial fish farming. Fish and Aquaculture Research Station. Dor. Israel, John Wiely and Sons Ins. New York, Toronto.

Jakson, M. L. (1967). Soil chemical analysis. Constable and Co. Ltd. London.

Kilmer, V. J. and Alexander, L. T. (1949). Methods of making mechanical analysis of soil. Soil Sci., 58 . $15-24$.

Mageed, A. A. A. (1996). Zooplankton assemblages and their role as natural food for the cultivated fishes in El-Fayoum fish farms. Bull. Fac. Sci., Zagazig Univ., 18 (2). 330 - 341. 
Pearson, T. H. and S. O., Stanley (1976). The benthic ecology of some shetland voes. Biology of benthic organisms, $11^{\text {th }}$ European Symposium on Marine Biology. Galway ed. Keegan B.F., P. O. Ceidigh. Perhamon Press Oxford. $503-512$.

Pennak, R. W. (1953). Freshwater invertebrates of the United States. University of Colorado- The Ronold Press Company, New York, 769 pp.

Row, G. T.; P. T. Pollons and R. L. Huedrich (1975). Quantitative biological assessment of the benthic fauna in deep basins of the Gulf of Main, $J$. Fish. Res. Bd. Canada, 32 . 1805 - 1817.

Smith, M. E.; B. J., Wyskowski; C. M., Brooks; C. T., Driscoll and C. C., Cosentini (1990). Relationships between acidity and Adirondack Mountains, New York, Can. J. Fish. Aquat. Sci., 47 . 1318 - 1329.

Smith, R. I. (1955). Salinity variation in interstitial water of sand at Kames Bay, Millport, with reference to the distribution of Neries diversicolor. J. Mar. Biol. Ass. U. K, 34 . 33 - 46.

Smith, R. I. (1956). The ecology of the Tamar Estuary VII. Observation on the interstitial salinity of the intertidal muds in the estuarine habitat of Neries diversicolor. J. Mar. Biol. Ass. U. K, 35 . 81 - 104.

Stephenson, W. and W. T., Williams (1971). A study of benthos of son bottoms, Sek harbour, New Guinea, using numerical analysis. Aust. J. Mar. Freshwater Res., 22 . 11 - 34.

Welch, P. S. (1952). Limnology, $2^{\text {nd }}$ edition, New York, Toronto, London, McGraw Hill book Company Inc., 528 pp. 
Table (t): Sorme chancteristies of fish pond's water and thelr aumber of slocked

Tishes.

\begin{tabular}{|c|c|c|c|c|c|c|c|c|}
\hline \multirow[b]{2}{*}{$\begin{array}{l}\text { Pond } \\
\text { nn. }\end{array}$} & \multirow{2}{*}{$\begin{array}{l}\text { Pond } \\
\text { area } \\
\text { (Prodden) }\end{array}$} & \multicolumn{2}{|c|}{ Nember a t nowet } & \multirow[b]{2}{*}{ plt } & \multirow[b]{2}{*}{$\begin{array}{l}\text { D. } 0 . \\
\mathrm{mgl}\end{array}$} & \multirow[b]{2}{*}{$\begin{array}{c}\text { EC } \\
\text { Nentromen }\end{array}$} & \multirow[b]{2}{*}{$\begin{array}{l}\mathrm{NO}_{3}{ }^{\circ} \\
\mathrm{m}_{k}\end{array}$} & \multirow[b]{2}{*}{$\mathrm{PO}^{\prime} \cdot$} \\
\hline & & Tilupin & Medil & & & & & \\
\hline 1 & 3.0 & 25000 & 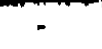 & 8.42 & 7.62 & 25.4 & 1083 & 12.9 \\
\hline 2 & 4.0 & 12000 & 4000 & 8.86 & 7.80 & 14,8 & 220 & 74.7 \\
\hline 3 & 3.25 & 20000 & 7200 & 8.40 & 7.95 & 23,0 & 166 & 136.5 \\
\hline 4 & 3.5 & - & 5000 & 8.62 & 10.80 & 7.6 & 150 & 23.2 \\
\hline 5 & 5.5 & - & 15000 & 8.73 & 9.0 & 12.2 & 3.0 & 28.3 \\
\hline 6 & 3.3 & 15000 & 3000 & 8.50 & 9.1 & 13.9 & 8.0 & 30.9 \\
\hline 7 & 5.0 & 10000 & 15000 & 8.66 & 9.0 & 18.3 & 7.0 & 97.8 \\
\hline 8 & 8.0 & 10000 & 15000 & 8.69 & 8.2 & 11.2 & 37.0 & 772.6 \\
\hline 9 & 7.0 & - & 15000 & 8.12 & 4.99 & 3.5 & 45.0 & 23.2 \\
\hline 10 & 8.2 & - & 18000 & $8.50^{\circ}$ & 13.8 & 4.3 & $43 ! .0$ & 25.8 \\
\hline
\end{tabular}

Tạble (2): Particle size distribution of Jish pond's sediment.

\begin{tabular}{|c|c|c|c|c|c|}
\hline \multirow{2}{*}{$\begin{array}{l}\text { Pand } \\
\text { no. }\end{array}$} & \multicolumn{4}{|c|}{ Particle she distributlon $\%$} & \multirow[b]{2}{*}{ Soll Teriere } \\
\hline & C. aned & F. sand & Silt & Chay & \\
\hline 1 & 1.99 & 32.61 & 33.92 & 31.48 & Clay loam \\
\hline 2 & 20.89 & 47.99 & 18.15 & 12.97 & Sandy loam \\
\hline 3 & 11.36 & 22,40 & 22.93 & 43.31 & Clay \\
\hline 4 & 0.39 & 10.18 & 24,84 & 64.59 & Clay \\
\hline 5 & 34.22 & 37.29 & 16.62 & 11.87 & Sandy loam \\
\hline 6 & 12.47 & 22.64 & 16.15 & 48.47 & Clay \\
\hline 7 & 2.73 & 32.60 & 32.85 & 31.82 & Cloy losp \\
\hline-8 & 2.35 & 31.13 & 33.13 & 33.39 & Clay loam \\
\hline 9 & 15.79 & 37.05 & 23.58 & 23.58 & Sandy clry loam \\
\hline 10 & 2.84 & 17.36 & 26.60 & 53.20 & Clay \\
\hline
\end{tabular}


Table (3): Some chemical properties of lish pond sedimeat in El-Fayoun Ginvernorale.

\begin{tabular}{|c|c|c|c|c|c|c|c|c|c|c|}
\hline Pond no. & O.At. & pll & $\bar{x}:$ & " $\mathrm{Nal}$ & $\mathbf{K}^{\prime}$ & $\mathrm{Ca}^{\circ}$ & $\mathrm{Mg}^{\prime \prime}$ & $\mathrm{HCO},{ }^{\circ}$ & $\mathbf{a t}$ & $500^{\circ}$ \\
\hline 1 & 091 & 8.20 & 3.30 & 20.43 & 0.65 & 0.5 & 3.0 & 0.6 & 8.4 & 15.58 \\
\hline 2 & 0.41 & 8.40 & 1.70 & 15.00 & 0.85 & 0.3 & 1.2 & 1.0 & 4.0 & 12.35 \\
\hline 3 & 0.91 & 8.15 & 3.00 & 20.43 & 1.17 & 0.8 & 1.2 & 1.4 & 9.8 & 12.40 \\
\hline 4 & 1.03 & 8.10 & 2.10 & 17.39 & 0.60 & 0.7 & 0.6 & 1.4 & 6.0 & 11.89 \\
\hline 5 & 0.39 & 8.30 & $170^{\circ}$ & 15.22 & 0.46 & 0.6 & 1.0 & 0.4 & 5.0 & 11.88 \\
\hline 6 & 052 & 8.25 & 2.10 & 17.61 & 0.60 & 4.6 & 1.1 & 1.0 & 6.4 & $12.5 t$ \\
\hline 1 & {$[n]$} & 8.10 & 390 & 23.91 & 0.990 & 0.8 & 2.6 & 1.2 & 14.0 & 13.10 \\
\hline 8 & 091 & 8.10 & 2.15 & 18.48 & 0.49 & 0.5 & 0.9 & 1.0 & 8.4 & 10.97 \\
\hline 9 & 169 & 8.00 & 2.60 & 19.57 & 0.74 & 0.7 & 1.9 & 1.2 & 8.6 & 13.11 \\
\hline 10 & 0.65 & 8.05 & 3.90 & 23.3 & 0.81 & 0.7 & 2.2 & 0.7 & 12.0 & 14.3 \\
\hline
\end{tabular}

lahle (4): Average iumber (organisms.m. ${ }^{-1}$ ) and wcight (C.F.W.m. ${ }^{-2}$ ) of different benthic groups recorded in fish ponds.

\begin{tabular}{|c|c|c|c|c|c|c|c|c|c|c|}
\hline \multirow[b]{2}{*}{ Pond No. } & \multicolumn{2}{|c|}{ Annelidn } & \multicolumn{2}{|c|}{ Crestucen } & \multicolumn{2}{|c|}{ Insecte } & \multicolumn{2}{|c|}{ Moltasc: } & \multicolumn{2}{|c|}{ Totnl } \\
\hline & $\mathbf{N}$ & 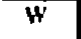 & $\mathbf{N}$ & $\mathbf{w}$ & 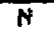 & $w$ & $\mathrm{~N}$ & W & $N$ & $w$ \\
\hline 1 & 2.1 & 0.100 & $16 x$ & $0.14 \pi$ & 144 & 2.926 & - & - & 336 & 3.164 \\
\hline 2 & 48 & 5.868 & 8 & 0.000 & 504 & 2.551 & 40 & 2.16 & 600 & 10.584 \\
\hline 3 & 392 & 37.44 & 144 & 9.800 & 8 & 0.104 & - & - & 544 & 47.84 \\
\hline 4 & - & - & 860 & 0.450 & 40 & 0.114 & - & - & 900 & 0.564 \\
\hline 5 & - & - & 96 & 22.346 & 136 & 0.517 & - & - & 232 & 22.863 \\
\hline h & 6.1 & 9.57 & 164 & 0.108 & 224 & 0.88 & - & - & 452 & 10.558 \\
\hline 7 & . & . & 52 & 3.218 & 80 & 0.221 & - & . & 132 & 1439 \\
\hline$R$ & . & - & 168 & 14.41 & 80 & 0.308 & . & - & 248 & 14.718 \\
\hline 9 & $\AA$ & $0 \leqslant 16$ & 496 & 15.237 & 104 & 0.814 & - & - & sot & 16.87 \\
\hline 10 & $4 \pi$ & 6282 & 272 & 0.181 & 16 & 0.146 & . & - & 336 & 6.609 \\
\hline
\end{tabular}

$N$ nutuher of trganisms. $m^{-2}$.

W. (iriml fresh Weight. $\mathrm{m}^{2}$ 


\begin{tabular}{|c|c|c|c|c|c|c|c|c|c|}
\hline & 表 & & 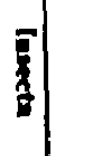 & & ? & & $\frac{2}{5}$ & & \\
\hline$\underline{\varepsilon}$ & : & 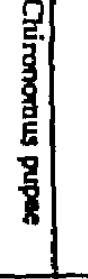 & $\begin{array}{l}\text { 暍 } \\
\frac{3}{3} \\
\frac{5}{5} \\
8\end{array}$ & |ֶ: & | & | & 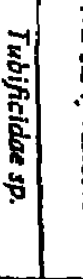 & |ִ & 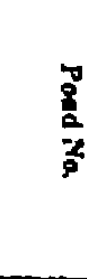 \\
\hline 岁 & $\cdot$ & $\cdot 1$ & $E$ & $\cdot$ & $\cdot$ & a & $\approx$ & & 2 \\
\hline 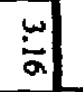 & .1 &. & $\begin{array}{l}\mathbf{n} \\
\mathbf{D} \\
\mathbf{\omega}\end{array}$ &. & . & i. & 항 & . & $\Rightarrow$ \\
\hline 잉 & t) & 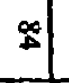 & : & . & $\cdot$ & $\infty$ & $\cdot$ & 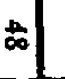 & 2 \\
\hline 형 & N. & 잉 & \begin{tabular}{l|} 
No \\
$\hat{0}$ \\
\end{tabular} & . & & 을 &. & 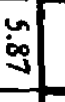 & 7 \\
\hline$\tilde{E}$ &. & $\cdot 1$ & $\infty$ & a & 2 & $\bar{q}$ & . & | & 2 \\
\hline : & 1 & . & 年 & $\begin{array}{l}0 \\
3 \\
3\end{array}$ & $\begin{array}{l} \\
\\
\end{array}$ & 8 & $\therefore$ & 可 & 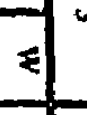 \\
\hline \$) & $\cdot$ & $\cdot$ & t & . & $\cdot$ & 吅 & ' & . & $z$ \\
\hline 영 & & & $\Rightarrow$ & & & 品 & . & ' & ₹ \\
\hline 岕 &. & $\infty$ & $\bar{\infty}$ & $\frac{\mathbf{D}}{\mathbf{D}}$ & $\dot{t}$ & $\cdot$ & . &. & -4 \\
\hline $\begin{array}{c}0 \\
0 \\
\vdots \\
0\end{array}$ & 1 & 요 & $\stackrel{i}{i}$ & (:) & 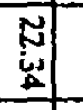 &. & . & . & $\Rightarrow$ \\
\hline 怘 & $\cdot$ & ' & $\mathbb{N}$ & is & ' & $\overline{\vec{N}}$ & . & 8 & 2 \\
\hline 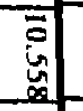 & . &. & : & 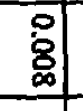 & . & 맘 & . & घ] & 7 \\
\hline$\overline{\mathrm{N}}$ & . & . & $\approx$ & $\cdot$ & $\infty$ & \pm & . & 1 & 2 \\
\hline$\ddot{\mathbf{E}}$ & &. & : & & 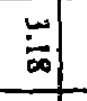 & : & . & ' & $\mp$ \\
\hline $\begin{array}{l}n \\
+\infty\end{array}$ & ' & ' & 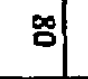 & ' & $\approx$ & $\mathbf{E}$ & + & ' & z) \\
\hline त & . & . & 물 & $:$ & 可 & $\underline{\sim}$ & . & & $\Rightarrow$ \\
\hline : & . & . & a & $\infty$ & $\ddot{N}$ & . & . & $\infty$ & 2 \\
\hline \begin{tabular}{|l|}
$\vec{a}$ \\
0 \\
0
\end{tabular} & . & . & 뭉 & : & $\overrightarrow{8}$ & : & . & $\begin{array}{l}0 \\
a \\
a \\
a\end{array}$ & 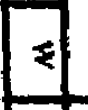 \\
\hline 㟔 & ' & $\infty$ & $\infty$ & $\overline{\mathbf{q}}$ & $\cdot$ & 文 & ' & 尧 & $z$ \\
\hline$\ddot{a}$ & . & \$ิ ڤ్ & 영 & 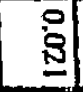 & & 히 & . & 查 & $\exists$ \\
\hline
\end{tabular}




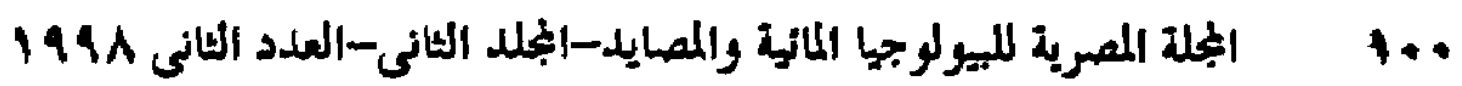

لانقاريات القاع الككيرة وعلاتها بخصائص رسويات القاع فى المزٔرع السمكية

محمل رضا على فيشار م- رجب عبد الرجال محمد

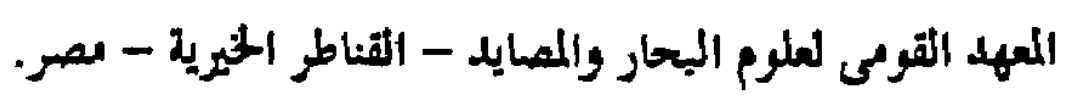

كمت دراسة بعض المهراص الكيميائية و الميكانيكيه لرسوبيات القاع بالاضافه إلى تكوين

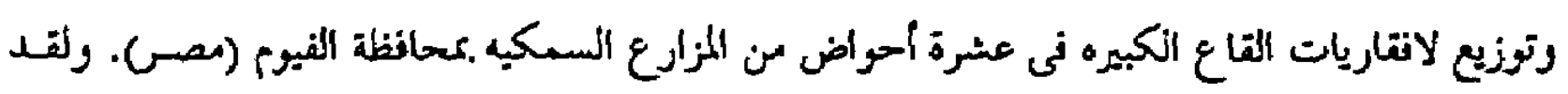

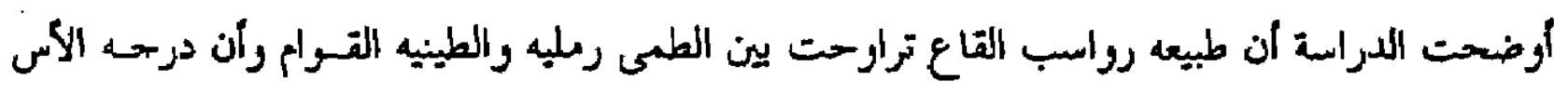

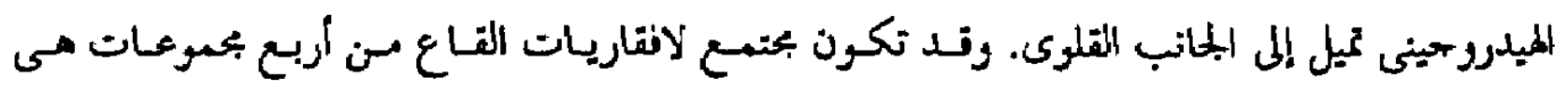

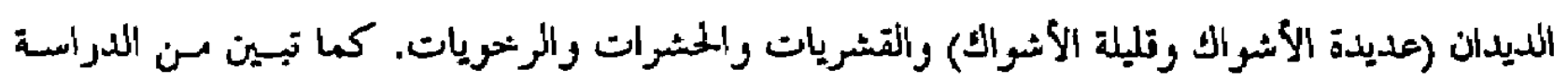

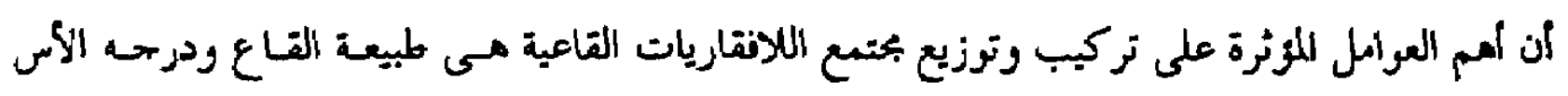

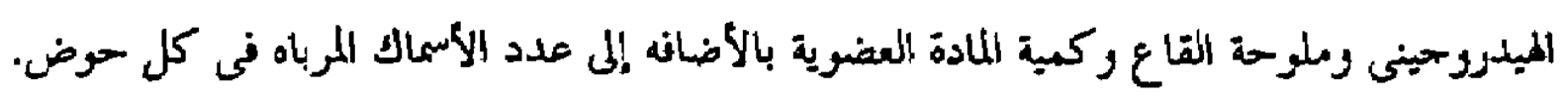

